\title{
KELOMPOK JURNALISTIK SISWA SMPIT ISTANA MULIA
}

\author{
Damayanti'), Azwar $^{2)}$, Anjang Priliantini' ${ }^{3)}$ \\ ${ }^{1}$ Program Studi Ilmu Komunikasi, FISIP, UPN "Veteran” Jakarta \\ damay.masduki@gmail.com,azwarstmalaka@upnvj.ac.idanjangpriliantini6@gmail.com
}

\begin{abstract}
Abstrak
Media adalah salah satu wacana yang digunakan dalam proses penyampaian dan penerimaan pesan atau informasi di antara dua orang atau lebih dengan harapan terjadinya pengaruh yang positif atau menimbulkan efek tertentu yang diharapkan. Kemampuan dalam mengelola informasi baik secara konten maupun layout akan sangat membantu stakeholder dalam menggunakan informasi tersebut untuk berbagai kebutuhannya. Oleh karena itu, sangat penting untuk memberikan edukasi mengenai pengelolaan media online utamanya penulisan jurnalistik online dalam menyampaikan informasi melalui media tersebut. Di SMPIT Istana Mulia Karangbolong, Anyer, Serang, Banten yang berbasis teknologi informasi, penggunaan teknologi informasi merupakan kegiatan yang memang dilakukan dalam berbagai kegiatan belajar. Salah satunya adalah penggunaan media sosial dan blog. Namun, untuk penggunaan jurnalistik online belum dilakukan karena beberapa keterbatasan. Karena keterbatasan tersebut, maka kegiatan IPTEK Bagi Masyarakat ini dilaksanakan oleh Prodi Ilmu Komunikasi UPN "Veteran” Jakarta.
\end{abstract}

Kata kunci: Jurnalistik Online, SMPIT Istana Mulia, UPNVJ.

\section{PENDAHULUAN}

Kegiatan Pelatihan Jurnalistik Media Online Kepada Siswa Sekolah Penengah Pertama Informasi Teknologi (SMPIT) Istana Mulia, di Kelurahan Karangbolong, Kecamatan Anyer, Kabupaten Serang, Provinsi Banten merupakan salah satu program pemberdayaan yang dimaksudkan untuk memperkaya kemampuan dalam melakukan penyampaian informasi melalui keterampilan melakukan kegiatan jurnalistik media online siswa-siswa Sekolah Menengah Pertama Informasi Teknologi (SMPIT) Istana Mulia.

Pelatihan ini diselenggarakan dengan latar belakang pentingnya pengetahuan mengenai teknik penulisan jurnalistik media online bagi siswasiswa Sekolah Menengah Pertama Informasi Teknologi (SMPIT) Istana Mulia yang belum dikuasai. Pilihan memberikan pelatihan jurnalistik online karena dewasa ini, jurnalistik online semakin berkembang di Indonesia bahkan dunia. Perkembangan media baru ini tidak hanya di wilayah-wilayah perkotaan, tetapi sudah merasuk sampai ke daerah, termasuk di daerah Karangbolong, Anyer, Serang, Provinsi Banten. Perkembangan teknologi ini harus diimbangi dengan kemampuan Sumber Daya Manusia (SDM) untuk memanfaatkannya kepada hal-hal yang positif.

Jika perkembangan media online ini tidak diimbangi dengan kemampuan Sumber Daya Manusia (SDM) untuk memanfaatkannya atau menganalisisnya, maka besar kemungkinan masyarakat, khususnya generasi muda terpapar efek negatif media. Efek negatif media ini bisa dikelompokkan ke dalam banyak hal seperti terkait moralitas (pornografi), ideologi yang tidak sesuai dengan Pancasila, kejahatan dunia maya (cyber crime) dan lain sebagainya. 
Berdasarkan latar belakang inilah, tim pengabdian kepada masyarakat, Program Studi Ilmu Komunikasi, Fakultas Ilmu Sosial dan Ilmu Politik Program Studi Ilmu Komunikasi Universitas Pembangunan Nasional "Veteran" Jakarta (UPN Veteran Jakarta) bersama dengan tim Media Online TeropongSenayan.com melakukan kegiatan pengabdian masyarakat untuk melatih kemampuan juralistik media online kepada siswa-siswa Sekolah Menengah Pertama Informasi Teknologi (SMPIT) Istana Mulia Karangbolong, Anyer, Serang, Provinsi Banten.

Jurnalistik online pada dasarnya merupakan turunan dari aktivitas jurnalisme pada umumnya. Hanya saja medianya saja yang berbeda yaitu tidak menggunakan media cetak seperti koran dan majalah atau media elektronik seperti televisi dan radio. Oleh sebab itu, terkait teknik jurnalistik online juga memiliki kekhasan tersendiri. Untuk memahami jurnalistik online, haruslah memahami pengertian jurnalistik secara umum.

\section{Tinjauan Pustaka}

Secara sederhana jurnalistik adalah seni berberita. Selanjutnya jurnalistik dapat diartikan sebagai kegiatan menghadirkan berita kepada pembaca, mulai dari kegiatan pencarian data di lapangan, memproduksinya menjadi tulisan, sampai menghadirkannya kepada khalayak pembaca. Pengertian tersebut dipertegas oleh beberapa pengertian tentang jurnalistik baik pengertian secara harfiah ataupun pengertian yang diberikan beberapa ahli (Azwar, 2017: 1). Untuk lebih jelasnya dapat dilihat beberapa pendapat yang akan diuraikan di bawah ini.

Onong Uchjana Effendy menyatakan bahwa jurnalistik adalah istilah yang berasal dari bahasa Belanda yaitu journalistiek. Dalam bahasa Inggris journalism, yang kedua kata tersebut bersumber pada kata journal. Journal sendiri merupakan terjemahan dari bahasa latin diurnal yang berarti harian atau setiap hari. Menurut Effendy, jurnalistik adalah teknik mengelola berita mulai dari mendapatkan bahan sampai kepada menyebar luaskan kepada khalaya. Apa saja yang terjadi di dunia apakah itu fakta peristiwa atau pendapat yang diucapkan seseorang. Jika diperkirakan akan menarik perhatian khalayak, akan menjadi bahan dasar jurnalistik, menjadi sumber berita untuk disebar luakan kepada masyarakat (Effendy, 2007: 95).

Dalam khasanah bahasa Indonesia kata jurnalistik adalah sesuatu yang menyangkut kewartawanan dan persuratkabaran. Sementara itu kata kewartawanan sendiri berasal dari kata wartawan yang berarti orang yang pekerjaannya mencari dan menyusun berita untuk dimuat di surat kabar, majalah, radio, dan televisi. Bersama jurnalistik juga ditemukan kata jurnalisme yaitu pekerjaan mengumpulkan, menulis, mengedit dan menerbitkan berita dalam surat kabar dan sebagainya. Sementara itu orang yang pekerjaannya mengumpulkan dan menulis berita dalam surat kabar dan sebagainya disebut jurnalis yang sepadan dengan wartawan (KBBI, 2003).

Paparan yang diuraikan di atas adalah pengertian jurnalistik secara harfiah atau pengertian berdasarkan terjemahan atau arti menurut kata. Sementara itu secara normatif jurnalistik adalah serangkaian kegiatan untuk mengungkapkan kebenaran, yang dilakukan dengan teknik tertentu. Pandangan lain tentang jurnalistik dapat dilihat pendapat yang mengatakan bahwa jurnalistik adalah suatu ilmu pengetahuan yang mempelajari bagaimana cara atau teknik mencari 
bahan berita hingga menyusunnya menjadi berita atau laporan yang menarik di dalam media massa cetak, media elektronik, maupun media baru (new media).

Terkait jurnalistik online, maka dapat diartikan sebagai serangkaian kegiatan untuk mengungkapkan kebenaran, yang dilakukan dengan teknik tertentu. Atau juga dapat diartikan sebagai suatu ilmu pengetahuan yang mempelajari bagaimana cara atau teknik mencari bahan berita hingga menyusunnya menjadi berita atau laporan yang menarik untuk media baru (new media).

Pembelajaran jurnalistik online pada dasarnya sama dengan pengajaran jurnalistik. Pengajaran jurnalistik di Indonesia dan di berbagai belahan dunia lainnya pada dasarnya dikelompokkan menjadi empat pilar besar. Keempat pilar besar itu adalah pertama laku wartawan kedua dinamika ruang redaksi, ketiga liputan dan keempat adalah penulisan. Laku wartawan berkaitan dengan etika wartawan ketika menjalankan tugas profesional mereka, baik di lapangan maupun dalam menulis.

Dinamika ruang redaksi tentu saja berkaitan dengan pengelolaan redaksi media. Berkaitan dengan tugas dan tanggungjawab mereka sebagai bagian dari pekerja profesional. Liputan atau reportase pada dasarnya adalah pembelajaran terkait bagaimana seorang wartawan mendapatkan data untuk diolah menjadi karya tulis. Sementara itu terkait penulisan tentu saja pembelajaran tentang hal-hal kepenulisan. Teknik menulis, cara-cara menulis dan lain sebagainya tentang bagaimana menuangkan apa yang sudah ada dalam kepala seorang wartawan menjadi tulisan.

\section{Identifikasi dan Perumusan Masalah}

Dari paparan analisis situasi pada bagian awal di atas dapat dilihat bahwa, generasi muda, khususnya siswa siswa Sekolah Penengah Pertama InformasiTeknologi (SMPIT) Istana Mulia, Karangbolong, Anyer, Serang, Banten merupakan aset bangsa dan generasi pelapis yang perlu dibekali berbagai keterampilan dalam menghadapi zaman globalisasi. Oleh sebab itu, perlu diadakan pelatihan yang dapat meningkatkan keterampilan dan kemampuan mereka agar lebih maksimal dalam dunia jurnalistik, khususnya jurnalistik online.

Adapun Identifikasi masalah dalam hal ini adalah:

1. Terbatasnya pemahaman dan pengetahuan siswa Sekolah Penengah Pertama Informasi-Teknologi (SMPIT) Istana Mulia, Di Karangbolong, Anyer, Serang, Banten tentang seluk beluk jurnalistik media online.

2. Terbatasnya kemampuan dan keterampilan siswa Sekolah Penengah Pertama Informasi-Teknologi (SMPIT) Istana Mulia, Di Karangbolong, Anyer, Serang, Banten, dalam pemanfaatan media online untuk meningkatkan kapasitas diri remaja.

3. Kurangnya kemampuan siswa Sekolah Penengah Pertama Informasi-Teknologi (SMPIT) Istana Mulia, Di Karangbolong, Anyer, Serang, Banten, dalam menganalisa konten mendia online.

\section{Tujuan Kegiatan}

Tujuan kegiatan pelatihan Jurnalistik Media Online untuk siswa Sekolah Penengah Pertama InformasiTeknologi (SMPIT) Istana Mulia, Di Karangbolong, Anyer, Serang, Banten adalah sebagai berikut :

1. Memberikan pemahaman dan pengetahuan mengenai seluk beluk jurnalistik media online. 
2. Memberikan pengetahuan dan keterampilan praktis dalam pemanfaatan media online untuk meningkatkan kapasitas diri remaja, khususnya siswa Sekolah Penengah Pertama Informasi-Teknologi

(SMPIT)

Istana Mulia, Di Karangbolong, Anyer, Serang, Banten.

3. Memberikan pengetahuan tentang cara menyebarkan konten-konten jurnalistik online melalui mediamedia sosial.

\section{Manfaat Kegiatan}

Kegiatan ini diharapkan akan memberikan manfaat langsung kepada siswa-siswa Sekolah Penengah Pertama Informasi-Teknologi (SMPIT) Istana Mulia, di Karangbolong, Kecamatan Anyer, Kabupaten Serang, Provinsi Banten sehingga dapat mereka aplikasikan dalam kehidupan sehari-hari.

Kemampuan dan keterampilan ini diharapkan dapat diterapkan dalam membuat konten media jurnalistik online yang sesuai dengan kaidah jurnalistik online dan dapat menularkan kepada lingkungannya untuk memahami jurnalisitk online sehngga meminimalisir kesalahan-kesalahan yang terjadi pada citizen jurnalism khusunya siswa SMPIT Iistana Mulia dalam penulisan konten jurnalstik online.

Dengan bekal pengetahuan dan keterampilan jurnalistik (keterampilan menulis berita, menulis feature dan menulis opini, selain keterampilan mengelola media online), agar dapat meningkatkan kapasitas remaja khususnya siswa SMPIT Istana Mulia, Di Karangbolong, Anyer, Serang, Provinsi Banten.

\section{Gambaran Umum Masyarakat Sasaran}

1. Lokasi

Lokasi pengabdian masyarakat berada di Sekolah Penengah Pertama
Informasi-Teknologi

(SMPIT)

Istana Mulia, Karangbolong, Anyer, Serang, Provinsi Banten.

2. Sasaran

Sesuai dengan Panduan

Pengabdian Masyarakat

Kemristekdikti, sasaran dalam kegiatan PKM adalah bagi meningkatkan keterampilan berpikir, membaca dan menulis atau keterampilan lain yang dibutuhkan (softskill dan hardskill).

3. Kegiatan

Kegiatan yang dilakukan dalam pelatihan jurnalistik media online ini adalah:

a. Mendengarkan presentasi materi jurnalistik media online dari nara sumber.

b. Praktik reportase (kajian pustaka, observasi dan wawancara) dalam rangka mencari data untuk menulis.

c. Praktik menulis berita, feature dan opini sebagai bagian dari jurnalistik media online.

Berdasarkan identifikasi masalah yang telah dikemukakan tersebut di atas maka tim merencanakan tiga tahap kerangka pemecahan masalah. Pada tahap pertama untuk pemecahan masalah terbatasnya pemahaman dan pengetahuan siswa-siswi Sekolah Menengah Pertama Informasi Teknologi (SMPIT) Istana Mulia, tentang konsep dan implementasi jurnalisme media online, maka tim pengabdian kepada masyarakat, Program Studi Ilmu Komunikasi, FISIP UPN Veteran Jakarta merencanakan pendekatan berupa presentasi di kelas.

Tahap kedua untuk meningkatkan kemampuan dan keterampilan jurnalisme media online, maka tim pelaksana akan memberikan praktek langsung serta simulasi dalam teknikteknik menulis untuk media online. Teknik menulis ini penting dipahami 
karena merupakan jiwa dari aktivitas jurnalisme termasuk jurnalistik online.

Pada tahap ketiga, tim pelaksana telah merencanakan program yang bermanfaat untuk membangun sikap kritis peserta dalam menganalisis media online. Sikap kritis ini penting karena pada dasarnya tidak semua informasi yang disampaikan oleh penulis dalam media online tersebut bermanfaat untuk anak-anak muda khususnya, untuk masyarakat pada umumnya. Oleh sebab itu perlu dilakukan dengan diskusi, tanya jawab dan problem solving berbagai kendala yang sering dialami dalam memahami konten media online.

\section{METODE PELAKSANAAN}

Metode pelaksanaan pada program pengabdian masyarakat ini, yaitu menyampaikan informasi dan memberikan pemahaman yang benar mengenai Jurnalistik Media Online, kepada siswasiswa Sekolah Menengah Pertama Informasi Teknologi (SMPIT) Istana Mulia, Karangbolong, Anyer, Serang, Provisni Banten. Hal ini dilakukan agar siswa-siswi dapat lebih mengerti mengenai hal-hal terkait jurnalistik online, khususnya teknik-teknik menulis dan menganalisis dalam media online. Selain itu, peserta juga diharapkan dapat mengaplikasikan pemahamannya tersebut dalam rangka menyampaikan informasi baik di lingkungan SMPIT Istana Mulia, maupun di lingkungan masyarakat sekitarnya serta masyarakat secara luas pada umumnya.

\section{Prosedur Kerja}

Adapun tahapan pelaksanaan program yaitu sebagai berikut:

Jadwal kerja kegiatan ini terdiri dari beberapa tahap yaitu:

1. Persiapan, Tahap ini dilakukan setelah persetujuan kegiatan ini direalisasikan yang menyangkut: waktu, tempat, dan keperluan yang dibutuhkan.

2. Pelaksanaan pelatihan Jurnalistik Media Online, Tahap ini adalah kegiatan utama berupa ceramah, diskusi, serta pelatihan tentang Jurnalistik Media Online, khususnya tentang berbagai aspek di dalamnya seperti tatacara, tata tempat, dll berdasarkan aturan yang berlaku bagi siswa-siswi Sekolah Menengah Pertama Informasi Teknologi (SMPIT) Istana Mulia, Banten.

3. Evaluasi Kegiatan, Tahap ketiga ini merupakan rangkaian kegiatan berupa evaluasi terhadap kegiatan tahap kedua dan persiapan laporan.

a. Pembuatan Laporan

1) Pembuatan Laporan Awal, Pembuatan laporan awal disesuaikan dengan hasil yang telah dicapai selama melakukan pembinaan terhadap siswa Sekolah Menengah Pertama Informasi Teknologi (SMPIT) Istana Mulia, Banten.

2) Revisi Laporan Revisi laporan dilakukan apabila terjadi kesalahan pada pembuatan laporan awal.

3) Pembuatan Laporan Akhir, Pembuatan laporan akhir dilakukan setelah melakukan revisi laporan agar dalam penyusunan laporan akhir diperoleh hasil yang lebih baik.

b. Rancangan Evaluasi

Adapun rancangan evaluasi dan indikator pelaksanaan kegiatan ini adalah berupa evalusi pasca kegiatan yang rencananya akan dilaksanakan setiap bulan selama empat bulan bertutur-turut dengan jadwal sebagai berikut:

1) Bulan kesatu: Peninjauan ke lokasi sebagai tahap awal 
melihat potensi individual dalam pengenalan dasar Jurnalistik Media Online.

2) Bulan kedua: Peninjauan ke lokasi dan wawancara serta penerapan dasar-dasar Jurnalistik Media Online.

3) Bulan ketiga: Peninjauan ke lokasi dan wawancara serta penerapan berbagai bentuk Jurnalistik Media Online.

4) Bulan keempat: Peninjauan ke lokasi dan peningkatan kualitas penerapan aktivitas Jurnalistik Media Online yang diterapkan kepada siswa-siswi Sekolah Menengah Pertama Informasi Teknologi (SMPIT) Istana Mulia, Provinsi Banten.

\section{Partisipasi Mitra}

1. Mitra yang akan memperoleh pelatihan Jurnalistik Media Online adalah siswa-siswi Sekolah Menengah Pertama Informasi Teknologi (SMPIT) Istana Mulia, Karangbolong, Anyer, Serang, Provinsi Banten, sejumlah anggota 150 siswa.

2. Mitra pendamping Media Online Teropong Senayan, akan berkolaborasi dengan Dosen Ilmu Komunikasi UPN "Veteran" Jakarta untuk memberikan materi kepada peserta. Media Online Teropong Senayan dipilih sebagai mitra pengabdian masyarakat karena mereka akan melengkapi Tim UPN "Veteran" Jakarta dalam hal taknis pengelolaan media online.

3. Media Online Teropong Senayan, juga akan bertindak sebagai media partner kegiatan, dengan salah satunya memberitakan kegiatan pengabdian masyarakat yang dilakukan Tim Dosen Ilmu Komunikasi FISIP

$$
\begin{aligned}
& \text { UPN "Veteran" Jakarta di } \\
& \text { media/majalah Teropong Senayan. }
\end{aligned}
$$

\section{HASIL DAN PEMBAHASAN}

Pelatihan jurnalistik online yang dilaksanakan dalam rangka kegiatan pengabdian masyarakat yang dilaksanakan oleh Program Studi Ilmu Komunikasi UPN "Veteran" Jakarta, dengan tema IPTEK Bagi Masyarakat (IBM) Kelompok Jurnalistik Siswa Sekolah Menengah Pertama InformasiTeknologi (SMPIT) Istana Mulia, di Karangbolong, Kecamatan Anyer, Kabupaten Serang, Provinsi Banten ini merupakan kegiatan pertama yang dilakukan di Pesantren Bisnis Istana Mulia.

Kegiatan Pengabdian pada Masyarakat di Desa Karangbolong, Kecamatan Anyer, Kabupaten Serang, Provinsi Banten dengan spesifikasi IPTEK bagi Masyarakat (IBM) ini dilaksanakan dalam tiga tahap. Tahaptahap tersebut pada awalnya direncanakan akan dilaksanakan selama 10 hari dengan beberapa materi dan tahapan pelaksanaan. Namun karena terbatasnya dana yang tersedia, maka kegiatan dilaksanakan dalam waktu 2 hari tetapi dengan tetap mempertahankan materi kegiatan yang sama, dengan waktu yang lebih singkat.

Sebelum menyampaikan materi kepenulisan secara mendalam, juga disampaikan tentang etika jurnalistik. Sebagaimana diketahui jurnalisme memiliki empat pilar. Keempat pilar pembelajaran jurnalistik itu sudah lama dipraktekkan oleh beberapa lembaga pelatihan jurnalistik atau sekolah jurnalistik di Indonesia. Salah satunya adalah Yayasan Pantau yang memberi perhatian besar terhadap pendidikan dan pelatihan jurnalis. Hal tersebut seperti disampaikan Anderas Harsono dalam buku "Sembilan Elemen Jurnalisme" 
(2010) bahwa Yayasan Pantau biasa membagi materi dalam empat kategori: (1) reportase, (2) penulisan, (3) laku wartawan, (4) dinamika ruang redaksi (newsroom)... reportase termasuk teknik wawancara, riset buku, internet, database dan pengamatan di lapangan. Penulisan termasuk latihan membuat deskripsi, menggunakan dialog, diskusi soal bagaimana membuat struktur cerita dan sebagainya. Kami biasa bikin dua struktur untuk pemula: piramida terbalik dan feature. Laku wartawan ya soal etika. Ia berhubungan dengan sumber, bagaimana memandang informasi, siapa yang layak dijadikan sumber dan sebagainya. Dinamika newsroom berkenaan dengan keragaman.

Tidak hanya Yayasan Pantau yang menerapkan empat pilar pengajaran jurnalistik itu, berbagai sekolah jurnalistik di Amerika Serikat juga menerapkan hal yang sama. Beberapa kota yang memiliki sekolah jurnalistik terkenal yang menghasilkan jurnalis beken dunia seperti di Boston dan New York juga menerapkan hal yang sama. Di Washinton D.C. tepatnya pada Committee of Concerned Journalist juga dikembangkan empat pilar besar pembelajaran jurnalistik ini.

Materi-materi yang dilaksanakan dirancang agar bermanfaat untuk memudahkan proses trasfer ilmu dan pemanfaatan teknologi kepada siswa SMPIT Istana Mulia. Materi-materi itu adalah:

1. Memahami Jurnalistik Online dan Etika Jurnalisme Online

2. Manajemen Media Online dan Praktik Manajemen Media Online

3. Teknik Mendapatkan Data Pustaka dan Praktik Mendapatkan Data Pustaka untuk Jurnalistik Online

4. Teknik Observasi untuk Jurnalistik Online dan Praktik Observasi untuk Jurnalistik Online
5. Teknik Wawancara untuk Jurnalistik Online dan Praktik Wawancara untuk Jurnalistik Online

6. Teknik Menulis Berita untuk Jurnalistik Online dan Praktik Menulis Berita untuk Jurnalistik Online

7. Teknik Menulis Feature untuk Jurnalistik Online dan Praktik Menulis Feature untuk Jurnalistik Online

8. Teknik Menulis Opini untuk Jurnalistik Online dan Praktik Menulis Opini untuk Jurnalistik Online

Materi-materi tersebut kemudian dibagi menjadi tiga tahap. Tahap-tahap itu dilaksanakan sebagaimana kegiatan berikut ini:

1. Pemahaman Tentang Jurnalisme Online

Tahap pertama dari kegiatan ini adalah memberikan pemahaman kepada siswa SMPIT Istana Mulia dengan tema "Memahami Jurnalistik Online dan Etika Jurnalisme Online" dan "Manajemen Media Online dan Praktik Manajemen Media Online". Materi ini penting untuk menjadi dasar bagi pemahaman siswa tentang jurnalisme online dan manajemen media jurnalisme onlinel.

Pada tahap pertama untuk pemecahan masalah terbatasnya pemahaman dan pengetahuan siswasiswi Sekolah Menengah Pertama Informasi Teknologi (SMPIT) Istana Mulia, tentang konsep dan implementasi jurnalisme media online, maka tim pengabdian kepada masyarakat, Program Studi Ilmu Komunikasi, FISIP UPN Veteran Jakarta melaksanakan pendekatan berupa presentasi di kelas.

Peserta yang terdiri dari 100 siswa SMPIT Istana Mulia mendapatkan materi tentang Jurnalisme Online yang diberikan 
Aris Eko Sedijono (Redaktur Pelaksana Teropong Senayan). Acara dipandu oleh Damayanti, S.Sos., M.Si dan bertempat di Aula Utama SMPIT Istana Mulia, acara yang dikemas seperti layaknya Seminar Jurnalistik itu berlangsung seru. Acara dimulai pada Pukul 9.00 WIB sampai dengan pukul 12.00.

$\begin{array}{rcr}\text { Pada } & \text { tahap ini } & \text { Redaktur } \\ \text { Pelaksana } & \text { Teropong } & \text { Senayan }\end{array}$
sebagai Mitra pengabdian masyarakat Prodi Ilmu Komunikasi UPNVJ memberikan materi tentang seluk beluk jurnalistik online dan etika jurnalistik online. Pada tahap ini, banyak siswa yang tidak bisa membedakan antara jurnalistik online dan media sosial di media. Karena sama-sama menggunakan media internet, persepsi siswa tentang media sosial dan media jurnalistik sama saja.

Hal tersebut terlihat dari pertanyaan-pertanyaan yang diajukan siswa, ketika menanggapi pembicara. Selain itu moderator juga mengajukan pertanyaan pembuka kepada tiga orang siswa tentang pendapat mereka tentang jurnalistik online. Semua siswa yang ditanya secara acak oleh moderator menjawab sama bahwa jurnalistik online adalah pemberitaan-pemberitaan dengan menggunakan media internet. Mereka belum bisa membedakan antara media sosial seperti blog, website pribadi, media warga, dan media jurnalistik online profesional.

Aris Eko Sedijono dalam kesempatan itu memaparkan bahwa Jurnalistik online sering disebut juga sebagai Jurnalis Internet (Internet Journalism), Jurnalis Website (Web Journalism), Jurnalis Digital (Digital Journalism), atau Jurnalis Siber (Cyber Journalism. Setiap jurnalis dewasa ini dituntut untuk bisa menjadi jurnalis online, karena hampir semua media cetak dan media elektronik kini telah memiliki versi media online agar bisa diakses oleh pembaca dari seluruh dunia.

2. Tahap kedua untuk meningkatkan kemampuan dan keterampilan jurnalistik

Pada tahap kedua, materi yang disampaikan adalah pemahaman tentang Teknik Mendapatkan Data Pustaka dan Praktik Mendapatkan Data Pustaka untuk Jurnalistik Online, Teknik Observasi untuk Jurnalistik Online dan Praktik Observasi untuk Jurnalistik Online, Teknik Wawancara untuk Jurnalistik Online dan Praktik Wawancara untuk Jurnalistik Online, Teknik Menulis Berita untuk Jurnalistik Online dan Praktik Menulis Berita untuk Jurnalistik Online, Teknik Menulis Feature untuk Jurnalistik Online dan Praktik Menulis Feature untuk Jurnalistik Online dan Teknik Menulis Opini untuk Jurnalistik Online dan Praktik Menulis Opini untuk Jurnalistik Online.

Setelah itu, tim UPN "Veteran" Jakarta membimbing siswa untuk melaksanakan berbagai praktek terkait dengan Jurnalistik seperti praktik wawancara, praktek menulis berita, feature dan opini. Tim pelaksana akan memberikan praktek langsung serta simulasi dalam teknik-teknik menulis untuk media online. Teknik menulis ini penting dipahami karena merupakan jiwa dari aktivitas jurnalisme termasuk jurnalistik online.

Dalam melaksanakan praktek pengumpulan data dan wawancara, serta praktek menulis, siswa dibagi menjadi tiga kelompok besar, yaitu: Kelompok A: Siswa Kelas 3 Kelompok B : Siswa Kelas 2 
Kelompok C : Siswa Kelas 1

Kelompok A, B, dan C ini kemudian dibagi lagi menjadi 5 kelompok yang terdiri dari 4 sampai dengan 6 siswa. Masing-masing kelompok mengajukan tema untuk mereka eksekusi, kemudian di bawah bimbingan instruktur mereka melakukan pencarian data dan melakukan wawancara dengan objek yang akan mereka tulis. Dalam tahap wawancara ini sudah dapat dilihat bagaimana kemampuan siswa untuk mengaplikasikan pelatihan yang sudah diberikan di kelas pada tahap pertama.

Walaupun masih dengan berbagai keterbatasan, akan tetapi terlihat perkembangan yang signifikan dari pembekalan yang diberika oleh tim terhadap siswa SMPIT Istana Mulia ini. Bahkan ketertarikan mereka terhadap jurnalistik semakin berkembang, karena mereka bisa menyalurkan minat dan bakat mereka dalam dunia jurnalistik.

3. Pada tahap ketiga, tim pelaksana telah merencanakan program yang bermanfaat untuk membangun sikap kritis peserta dalam menganalisis media online

Sikap kritis ini penting karena pada dasarnya tidak semua informasi yang disampaikan oleh penulis dalam media online tersebut bermanfaat untuk anak-anak muda khususnya, untuk masyarakat pada umumnya. Oleh sebab itu perlu dilakukan dengan diskusi, tanya jawab dan problem solving berbagai kendala yang sering dialami dalam memahami konten media online.

Membangun sikap kritis siswa ini adalah dengan melatih siswa untuk mengkritisi media. Masingmasing siswa diminta membaca beberapa berita dari sumber yang berbeda-beda, kemudian mereka diminta untuk menanggapinya sesuai pemahaman mereka. Pada tahap awal, siswa menanggapi berita apa adanya, sesuai pengalaman mereka sendiri.

Pada tahap selanjutnya, instruktur dari UPN "Veteran" Jakarta dan dari Teropongsenayan.com memberikan materi terkait pengenalan media. Dalam hal ini dijelaskan bahwa media memiliki fungsi-fungsi yang berbeda yaitu: fungsi informasi, fungsi kesinambungan, fungsi korelasi, fungsi mobilisasi, fungsi hiburan, fungsi pendidikan, fungsi pembangunan dan fungsi persuasi, serta pengawasan.

Pada tahap akhir kegiatan para santri yang belajar tentang jurnalistik online, menulis dan seberapa menariknya menjadi wartawan. Para santri diajarkan tentang hal-Hal terkait jurnalistik online dan ilmu menjadi wartwan, seperti bahasa jurnalistik dan cara berbicara pada narasumber agar dapat mudah mendapatkan informasi.

Selain itu mereka juga diajarkan tentang bahasa jurnalistik, tata cara berbicara kepada narasumber dan menulis laporan, praktek wawancara dan manajemen sosial media. Para santri diajarkan unsur membuat laporan, seperti $5 \mathrm{~W}+1 \mathrm{H}$, menggunakan unsur SPOK, agar tulisan dapat dimengerti pembaca. Mereka membuat tulisan dengan berbagai cerita untuk dinilai oleh pembimbingnya. Pelatihan ini memberikan manfaat bagi siswa untuk menguasai jurnalistik dan dorongan untuk berkarya dengan menulis di media sosial ataupun buku.

\section{SIMPULAN}

Pelatihan jurnalistik online yang dilaksanakan di Sekolah Menengah 
Pertama Informasi-Teknologi (SMPIT) Istana Mulia, di Karangbolong, Kecamatan Anyer, Kabupaten Serang, Provinsi Banten ini dilaksanakan dalam beberapa tahap. Pertama pemahaman, yaitu memberikan pemahaman kepada siswa SMPIT Istana Mulia dengan tema "Memahami Jurnalistik Online dan Etika Jurnalisme Online" dan "Manajemen Media Online dan Praktik Manajemen Media Online". Materi ini penting untuk menjadi dasar bagi pemahaman siswa tentang jurnalisme online dan manajemen media jurnalisme onlinel.

Tahap kedua untuk meningkatkan kemampuan dan keterampilan jurnalistik materi yang disampaikan adalah pemahaman tentang Teknik Mendapatkan Data Pustaka dan Praktik Mendapatkan Data Pustaka untuk Jurnalistik Online, Teknik Observasi untuk Jurnalistik Online dan Praktik Observasi untuk Jurnalistik Online, Teknik Wawancara untuk Jurnalistik Online dan Praktik Wawancara untuk Jurnalistik Online, Teknik Menulis Berita untuk Jurnalistik Online dan Praktik Menulis Berita untuk Jurnalistik Online, Teknik Menulis Feature untuk Jurnalistik Online dan Praktik Menulis Feature untuk Jurnalistik Online dan Teknik Menulis Opini untuk Jurnalistik Online dan Praktik Menulis Opini untuk Jurnalistik Online.

Pada tahap ketiga, tim pelaksana telah merencanakan program yang bermanfaat untuk membangun sikap kritis peserta dalam menganalisis media online. Sikap kritis ini penting karena pada dasarnya tidak semua informasi yang disampaikan oleh penulis dalam media online tersebut bermanfaat untuk anak-anak muda khususnya, untuk masyarakat pada umumnya. Oleh sebab itu perlu dilakukan dengan diskusi, tanya jawab dan problem solving berbagai kendala yang sering dialami dalam memahami konten media online.
Secara sederhana kegiatan ini mampu menjawab masalah-masalah yang terjadi di SMPIT Istana Mulia terkait dengan hal-hal berikut ini pertama dengan kegiatan ini mampu meningkatkan pemahaman dan pengetahuan siswa-siswa Sekolah Menengah Pertama Informasi Teknologi (SMPIT) Istana Mulia Karangbolong, Anyer, Serang, Banten tentang penulisan jurnalistik media online. Kedua dengan pelatihan ini mampu meningkatkan keterampilan siswa-siswa Sekolah Menengah Pertama Informasi Teknologi (SMPIT) Istana Mulia Karangbolong, Kecamatan Anyer, Kabuoaten Serang, Provinsi Banten dalam melakukan praktek dan aktivitas jurnalistik media online. Ketiga dengan kegiatan ini mampu meningkatkan kecakapan siswasiswa Sekolah Menengah Pertama Informasi Teknologi (SMPIT) Istana Mulia Karangbolong, Anyer, Serang, Banten dalam membangun apresiasi mereka berkaitan dengan jurnalistik media online.

\section{DAFTAR PUSTAKA}

Alwi, H. (2005). Kamus Besar Bahasa Indonesia Edisi Ketiga. Cetakan ke-3. Jakarta: Balai Pustaka

Azwar. (2017). Dasar-Dasar Jurnalistik. Bandung: Mujahid Pers.

Effendy, O.U. (2003). Ilmu, Teori dan Filsafat Komunikasi. Bandung: Penerbit Citra Aditya Bakti.

Harsono, A. (2002). Agama Saya Jurnalisme. Jakarta: Yayasan Pantau.

Kovach, B. dan Rosenstiel, T. (2002). Sembilan Elemen Jurnalisme; Apa yang Seharusnya Diketahui Wartawan dan Diharapkan Publik. Jakarta: Yayasan Pantau. 
Nasrullah, R. (2013). Media Cyber. Jogjakarta: Penerbit Idea Press.

. (2015). Media Sosial, Prespektif Komunikasi, Budaya, dan Sosiaoteknologi. Bandung: Sembiosa Rekatama.

Mulyana, D. (2001). Metodologi Penelitian Kualitatif. Bandung: PT.Rosda Karya. 